\title{
SOSIALISASI PENGENALAN POTENSI SUMBERDAYA KELAUTAN DENGAN PENDEKATAN BIOPROSPEKSI KELAUTAN KEPADA MASYARAKAT PESISIR LHOK BUBON ACEH BARAT
}

\section{THE SOCIALIZATION OF THE POTENCY OF MARINE RESOURCES INTRODUCTION IN MARINE BIOPROSPECTING APPROACH AT COASTAL OF LHOK BUBON, WEST ACEH}

\author{
${ }^{1}$ Mohamad Gazali \\ ${ }_{1}^{1}$ Prodi IImu Kelautan Fakultas Perikanan dan IImu Kelautan Universitas Teuku Umar \\ Korespondensi: mohamadgazali@utu.ac.id
}

\begin{abstract}
ABSTRAK
Sumberdaya pesisir dan laut menyedia berbagai manfaat untuk meningkatkan kesejahteraan masyarakat pesisir. Berbagai manfaat sumberdaya pesisir dan laut meliputi sumber pangan, non pangan dan obat-obatan. Berdasarkan survey lapangan bahwa sumberdaya pesisir dan laut yang tersebar di sepanjang pesisir Lhok Bubon meliputi makroalga, teripang, dan mangrove. Hal ini dapat menjadi acuan dalam memperoleh informasi terkait ketersediaan bahan baku biofarmaka. Kegiatan pengabdian kepada masyarakat dilaksanakan pada tanggal 7 April 2019 di Pantai Lhok Bubon Kecamatan Samatiga Kabupaten Aceh Barat. Metode pelaksanaan kegiatan pengabdian kepada masyarakat ini meliputi survey potensi sumberdaya pesisir dan laut, sosialisasi kegiatan pengabdian kepada masyarakat, dan gerakan bersih pantai. Dalam pelaksanaan kegiatan menunjukkan adanya kesadaran masyarakat pesisir dalam menjaga lingkungan pesisir dan laut. Selain itu, kegiatan pengabdian kepada masyarakat ini dimana masyarakat pesisir memperoleh berbagai informasi terkait dengan pemanfataan sumberdaya pesisir dan laut di desa Lhok Bubon Kecamatan Samatiga Kabupaten Aceh Barat.
\end{abstract}

Kata kunci : Bioprospeksi, Biofarmaka, Pesisir, Laut

\begin{abstract}
Coastal and marine resources provide several benefit for increasing the coastal prosperity. Several benefits of coastal and marine resources including food and non food sources and drugs. According to survey that coastal and marine resources that widespread alongside of Lhok Bubon coastal including macroalgae, sea cucumber and mangrove. It is to be benchmark to gain information related the provided of biopharmaca raw material. The empowering community activity was held in April 7, 2019 at the beach of Lhok Bubon Samatiga district West Aceh Regency. The method of activity icluding the survey of coastal and marine resources, the socialization of empowering community and beach clean movement. The activity showed the awareness of coastal community to keep the coastal and marine environment. In other hand, the empowering community activity which the coastal community obtained several informations related the utilization of coastal and marine resources in Lhok Bubon Village Samatiga District West Aceh Regency.
\end{abstract}

Keywords : Bioprospecting, biopharmaca, coastal, marine 


\section{PENDAHULUAN}

Indonesia merupakan negara kepulauan dengan kekayaan keanekaragaman hayati terbesar kedua setelah negara Brazil. Brazil mempunyai daratan yang luas (hutan amazon) sedangkan indonesia mempunyai jumlah pulau-pulau kecil yang banyak dengan lautan yang luas. Hal ini menjadikan Indonesia sebagai negara dengan keanekaragaman hayati laut (megabiodiversity) tertinggi di dunia (Primack et al., 1998). Keanekaragaman hayati kimia bahan alam dengan berbagai bioaktivitas potensial kemudian dikembangkan ke tahap penemuan obat-obatan.

Indonesia memiliki 7500 jenis tumbuhan obat yang telah diidentifikasi dan dimanfaatkan baru sekitar 940 jenis dari tumbuhan obat yang ada (Kemendag, 2017). Propinsi Aceh memiliki keanekaragaman hayati yang begitu pesat terutama wilayah barat selatan (Barsela) Aceh dengan karakteristik pesisir dan laut yang berhadapan dengan Samudera Hindia. Keanekaragaman hayati laut yang tersebar luas memiliki potensi dalam bidang bioprospeksi kelautan yang dapat dikembangkan dalam pengobatan penyakit pada manusia. Salah satu wilayah pesisir Barat Selatan yang memiliki potensi sumberdaya kelautan adalah makroalga laut. Menurut Gazali (2018) bahwa makroalga laut spesies Sargassum sp asal pesisir Lhok Bubon memiliki potensi sebagai agen antioksidan.

\section{Permasalahan}

Wilayah pesisir pantai Lhok Bubon Aceh Barat memiliki karakteristik geografis laut lepas yang berhadapan langsung dengan Samudera Hindia memiliki potensi keindahan laut yang memikat turis lokal dan mancanegara. Karakteristik pantai batuan karang mati dan berpasir yang merupakan substrat bagi biota laut (Gambar 1 dan 2). Namun, masyarakat pesisir Lhok Bubon belum memanfaatkan makroalga laut sebagai bahan baku biofarmaka untuk kebutuhan kesehatan manusia. Sementara, keberadaan biota laut cukup berlimpah di wilayah pesisir. Hal ini yang melatarbelakangi kami melakukan sosialisasi kepada masyarakat sekitar Lhok Bubon terkait potensi sumberdaya laut dengan pendekatan bioprospeksi kelautan.

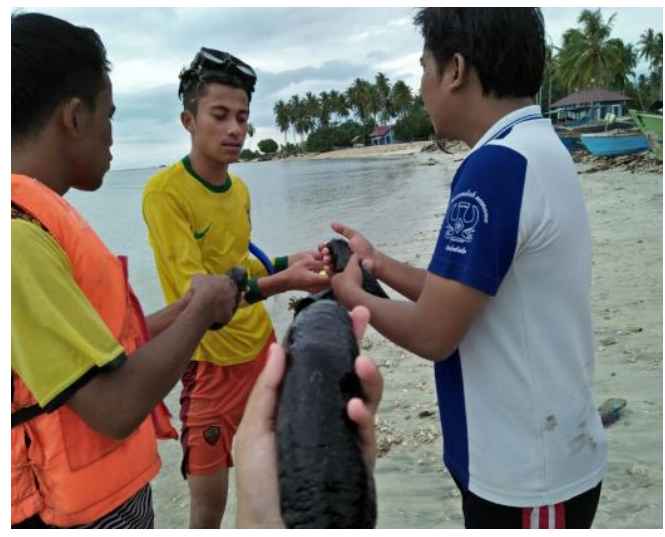

(a)

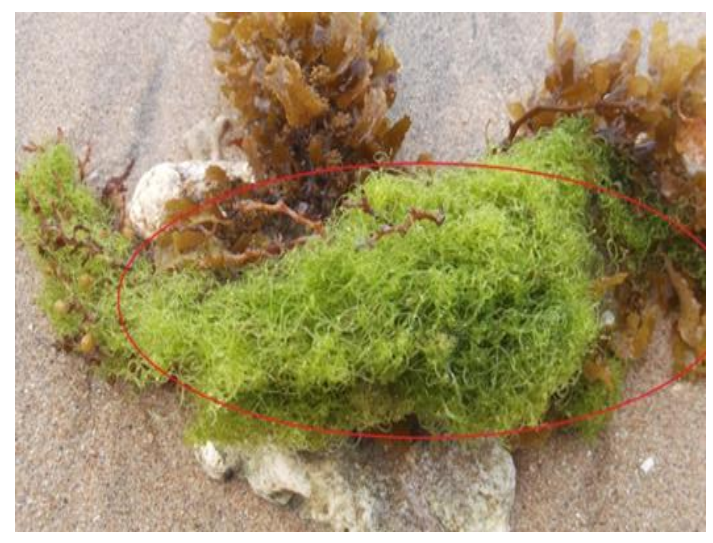

(b)

Gambar 1. Eksplorasi potensi sumberdaya laut, teripang laut(a) dan makroalga (b) Sumber : (Dokumentasi Pribadi, 2017). 
Selain itu, potensi sumberdaya kelautan lainnya yang memiliki kontribusi dalam bidang bioprospeksi kelautan yaitu komunitas mangrove yang tersebar di sepanjang pesisir. Akan tetapi dengan adanya aktivitas antropogenik meliputi kegiatan wisata pantai dan pembangunan untuk mendukung pariwisata. Kawasan pesisir Lhok Bubon memiliki beberapa spesies mangrove meliputi Rhizophora sp, Bruguiera sp, Sonneratia alba, Nypa fruticans dan beberapa mangrove ikutan (Gambar 3).

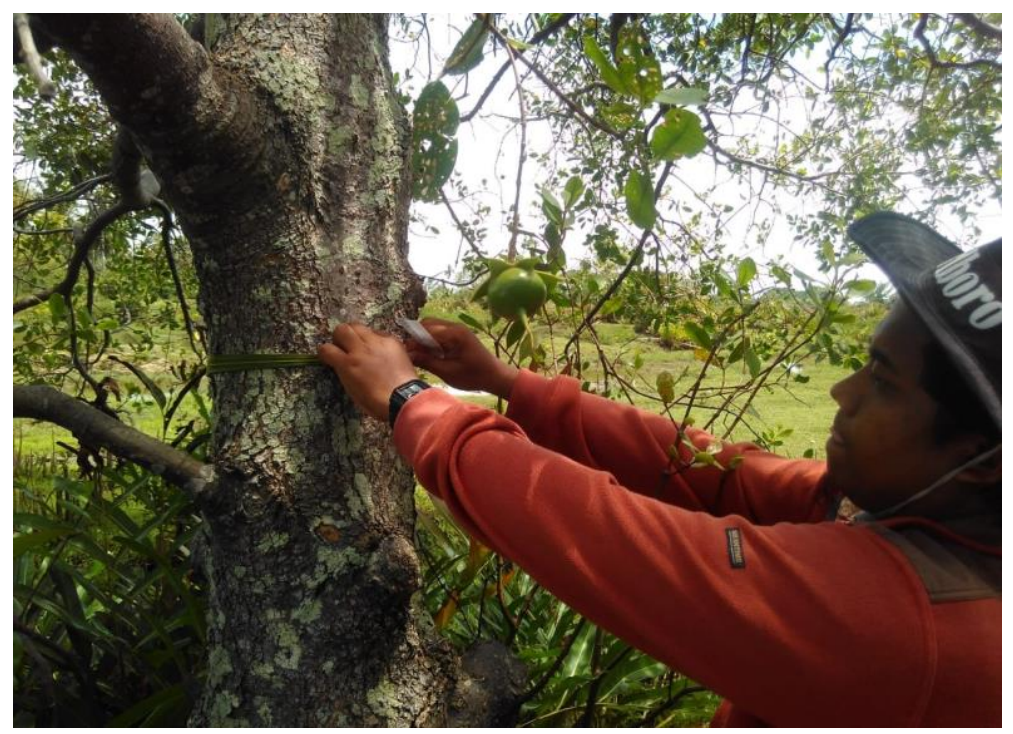

Gambar 3. Eksplorasi potensi sumberdaya laut berupa spesies mangrove

Sumber : (Dokumentasi Pribadi, 2019).

Permasalahan prioritas yang dihadapi dalam dinamika masyarakat pesisir Lhok Bubon yaitu belum adanya pengetahuan dan keterampilan tentang pemanfaatan potensi sumberdaya kelautan dalam bidang bioprospeksi kelautan. Oleh karena itu, perlunya adanya sosialisasi pengenalan bentuk-bentuk pemanfaatan sumberdaya kelautan dalam bidang bioprospeksi dan kedepan akan dibuat pelatihan kepada masyarakat pesisir terkait teknik pengolahan sumberdaya kelautan menjadi natural product.

\section{Tujuan Pelaksanaan}

Tujuan pelaksanaan kegiatan pengabdian kepada masyarakat ini adalah sebagai berikut :

1. Memberikan pemahaman dan pengetahuan kepada masyarakat pesisir Lhok Bubon terkait dengan potensi pemanfaatan sumberdaya kelautan dalam bidang bioprospeksi kelautan.

2. Membangun silaturahmi dengan masyarakat pesisir Lhok Bubon untuk membangun kerjasama yang baik kedepan

3. Mendorong mahasiwa dan dosen untuk ikut serta dalam melakukan kegiatan pengabdian kepada masyarakat di Lhok Bubon. 


\section{METODE PELAKSANAAN}

\section{Tempat dan Waktu}

Pelaksanaan kegiatan ini telah dilaksanakan pada tanggal 07 Maret 2019 di Pantai Lhok Bubon Gampong Lhok Bubon Kecamatan Samatiga Kabupaten Aceh Barat Propinsi Aceh (Gambar 4).

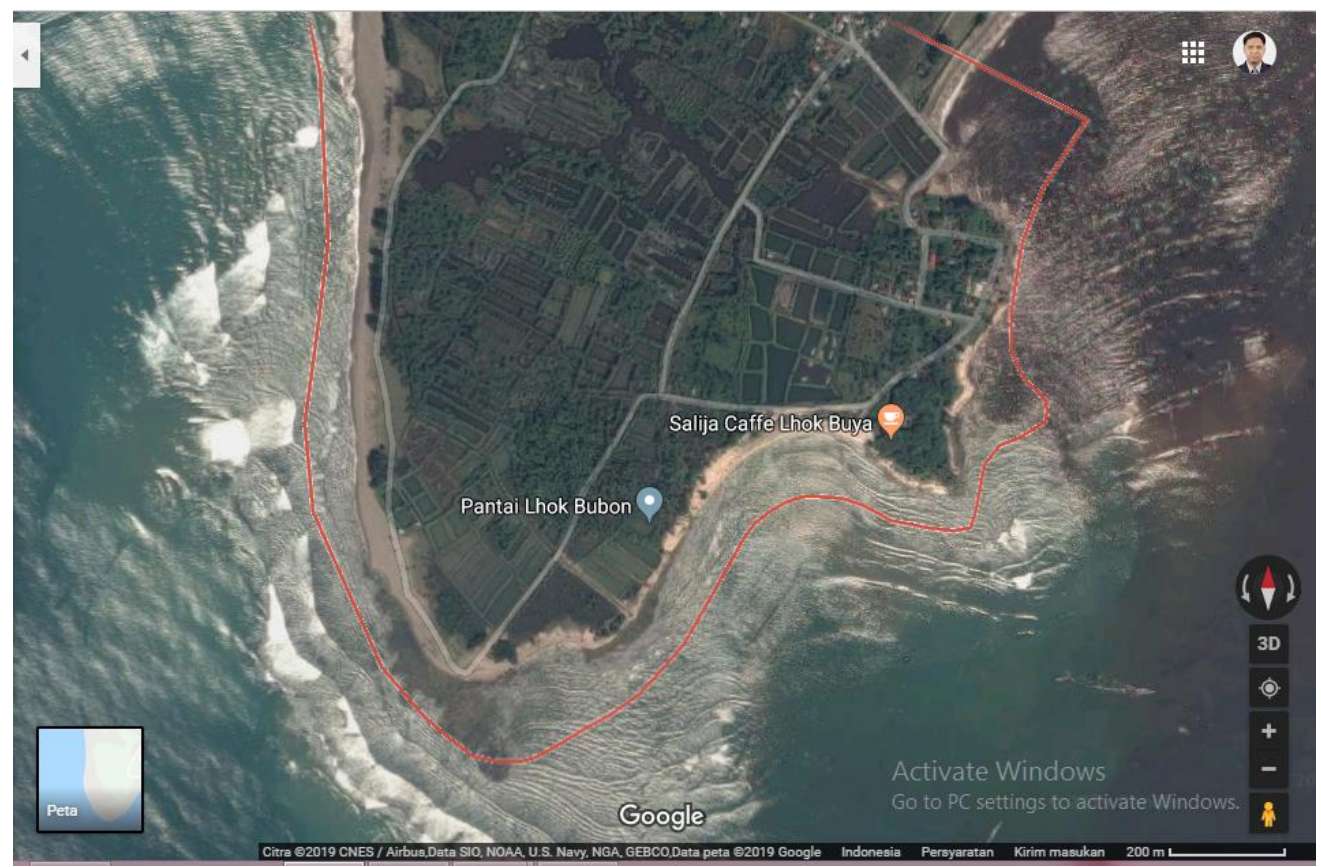

Gambar 4. Peta Lokasi Kegiatan Pengabdian kepada Masyarakat Sumber : (Google maps, 2019 )

\section{Teknik Pelaksanaan}

Teknik yang digunakan dalam menyelesaikan pemasalahan yaitu langkah awal dengan melakukan sosialisasi pengenalan potensi sumberdaya kelautan dalam bidang bioprospeksi kelautan. Adapun tahapan pekerjaan dalam menyelesaikan permasalahan dan sekaligus pencapaian tujuan program adalah sebagai berikut :

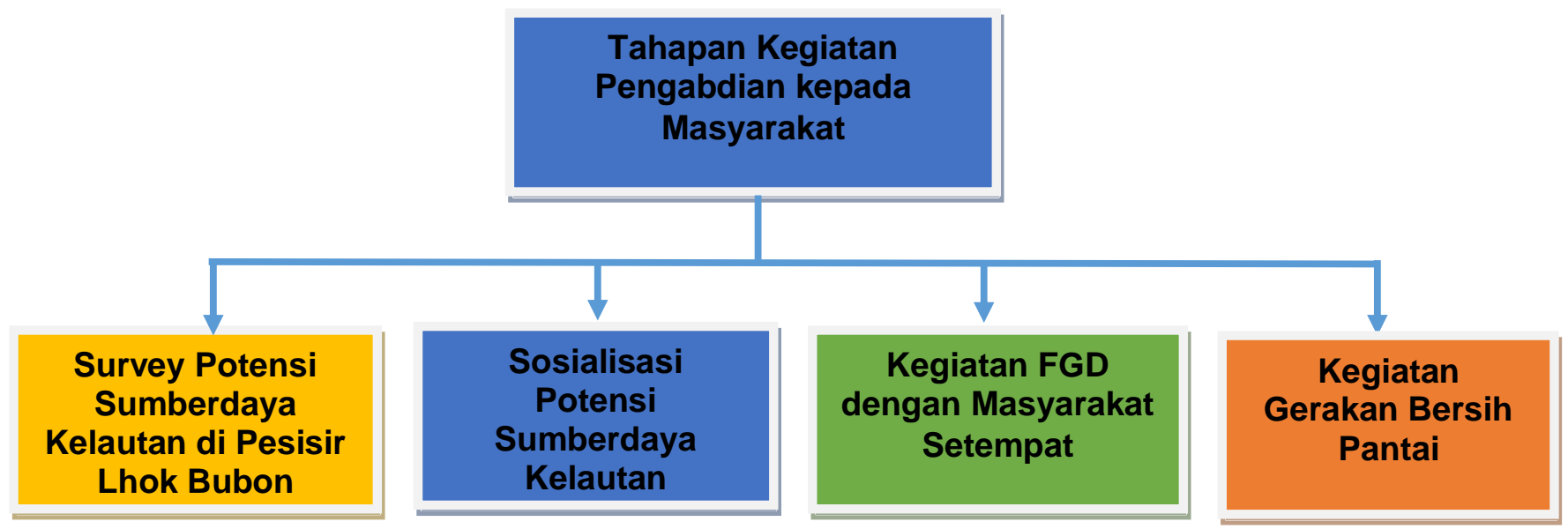

Gambar 5. Tahapan Pelaksanaan 


\section{HASIL DAN PEMBAHASAN}

\section{Sosialisasi Pengenalan Potensi Sumberdaya Kelautan}

Sosialisasi pengenalan potensi sumberdaya kelautan dalam bidang bioprospeksi kelautan yang dilaksanakan di Desa Lhok Bubon Kecamatan Samatiga. Materi sosialisasi yang disampaikan berkaitan potensi sumberdaya pesisir dan laut meliputi makroalga, mangrove, teripang dan lain-lain. Hal ini memberikan nilai tambah (value added) bagi kesejahteraan masyarakat pesisir. Kegiatan sosialisasi tersebut mendapatkan apresiasi dari masyarakat pesisir. Mereka berharap kedepan dapat memanfaatkan potensi sumberdaya kelautan yang ada di pesisir Aceh Barat (Gambar $6)$.

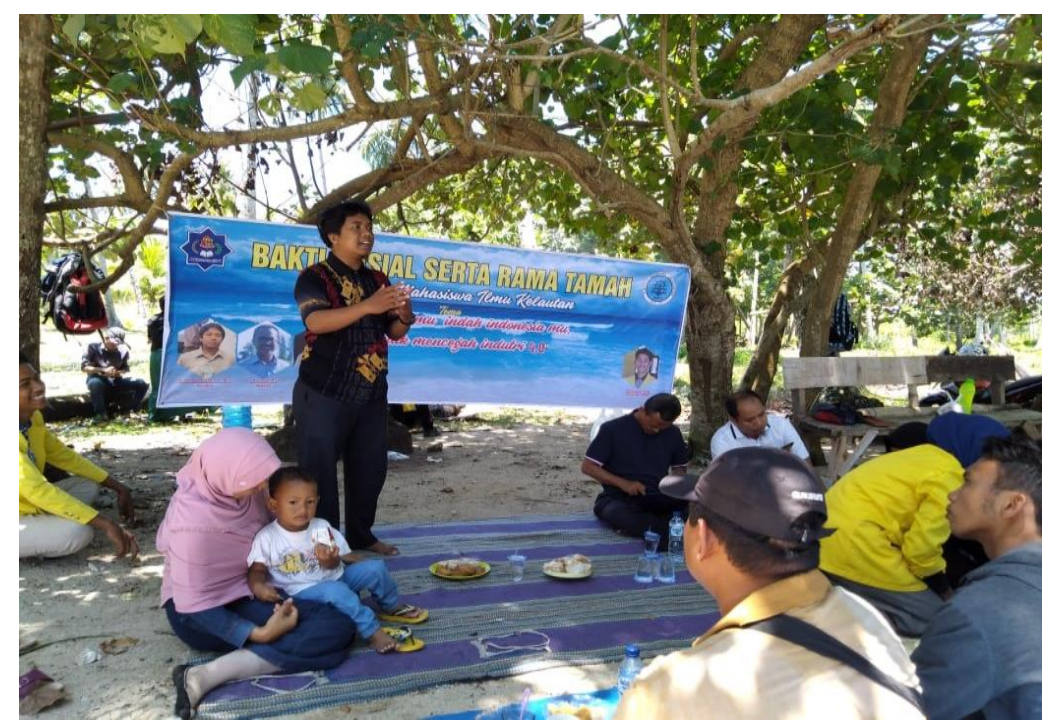

Gambar 6. Penulis memaparkan materi program pengabdian kepada masyarakat

Output dari kegiatan sosialisasi adalah memberikan pemahaman dan pengetahuan kepada masyarakat pesisir akan potensi sumberdaya kelautan yang dapat dikelola secara berkelanjutan. Hal ini tidak terlepas dari peran serta pemerintah dan perguruan Tinggi memberikan berbagai inovasi dalam pemanfaatan sumberdaya kelautan (Gambar 7).

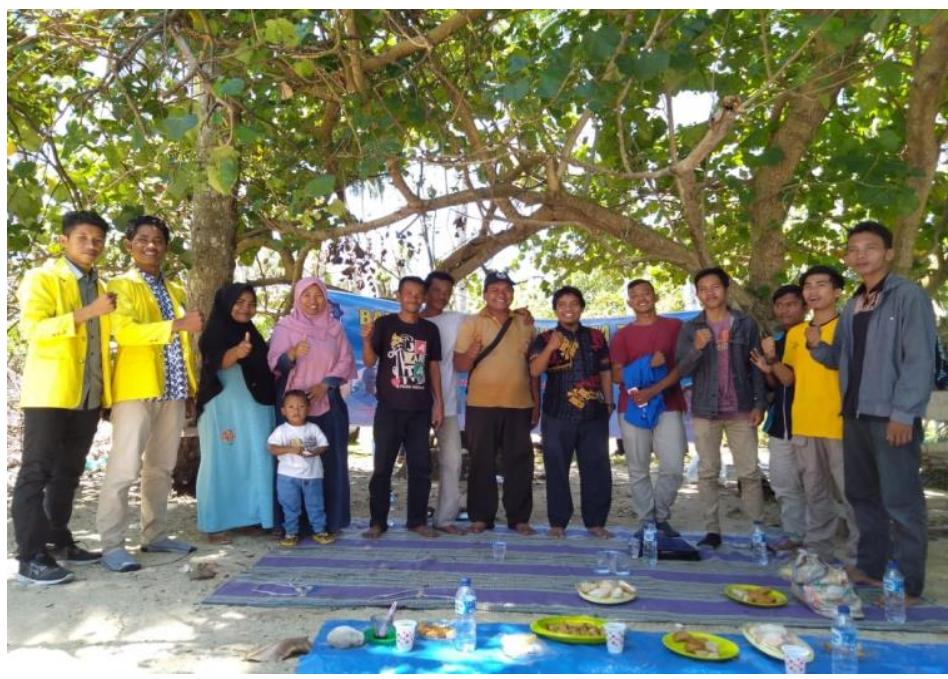


Gambar 7.Penulis bersama masyarakat pesisir dalam program pengabdian kepada

\section{Gerakan Bersih Pantai} masyarakat

Setelah kami memberikan pemaparan tentang potensi pemanfaatan sumberdaya pesisir dan laut yang di perairan Lhok Bubon. Kami melaksanakan gerakan bersih pantai melibatkan mahasiswa Program Studi IImu Kelautan FPIK UTU dan masyarakat pesisir. Hal ini bertujuan memberikan kesadaran kepada masyarakat dan mahasiswa akan pentingnya menjaga kebersihan pantai. Hal ini berpengaruh positif pada biota laut yang hidup disekitar pesisir pantai Lhok Bubon menjadi lebih mudah untuk berkembang dengan meminimalisir gangguan yang terjadi di lingkungan pesisir (Gambar 8).

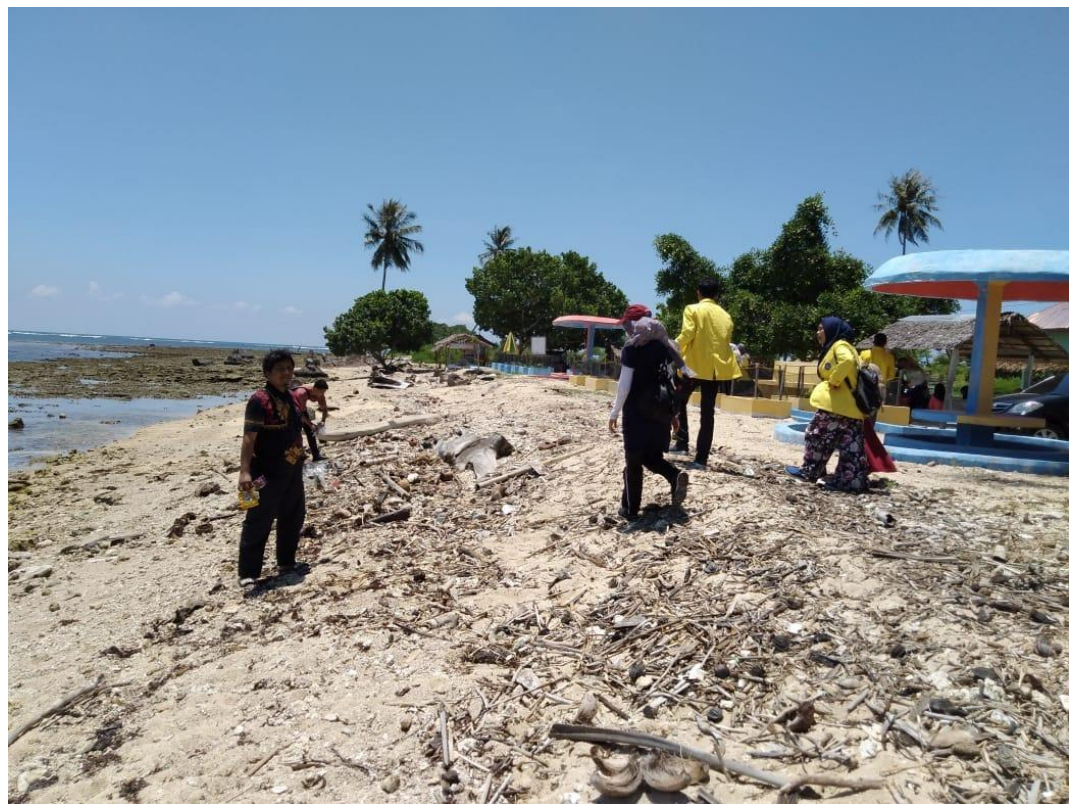

Gambar 8. Penulis melaksanakan gerakan bersih pantai Desa Lhok Bubon

Kegiatan gerakan bersih pantai memiliki dampak positif bagi lingkungan pesisir dan laut. Salah satu dampak positif yang dimiliki lingkungan pesisir adalah adanya kemampuan menyediakan potensi sumberdaya pesisir dan laut untuk meningkatkan kesejahteraan umat manusia.

\section{SIMPULAN DAN SARAN}

\section{Simpulan}

Berdasarkan hasil dan pembahasan di atas disimpulkan bahwa sosialisasi pengenalan potensi sumberdaya kelautan menunjukkan adanya :

1. Kesadaran pentingnya menjadi kebersihan pantai untuk menjaga keberlangsungan sumberdaya pesisir dan laut di Desa Lhok Bubon.

2. Pemahaman tentang pemanfaatan potensi sumberdaya kelautan secara berkelanjutan.

3. Upaya keberlanjutan program pengabdian kepada masyarakat melalui pelatihan/training tentang pemanfataan potensi sumberdaya kelautan yang ada di pesisir Lhok Bubon. 


\section{Saran}

1. Perlu adanya pelatihan capacity building bagi masyarakat pesisir Lhok Bubon dalam hal pengelolaan konservasi lingkungan pesisir dan laut secara berkelanjutan.

2. Perlu adanya regulasi dari pemeritah setempat dalam mengelola wisata pantai agar terkontrol dalam pengelolaannya.

\section{UCAPAN TERIMA KASIH}

a. Dalam mensukseskan kegiatan pengabdian kepada masyarakat ini tidak terlepas dari kerjasama yang baik dengan Himpunan Mahasiswa IImu Kelautan (HMIK) atas kerjasama dan kekompakan dalam kegiatan sosialisasi sosialisasi kami ucapkan terima kasih yang setinggi-tingginya.

b. Ucapan terima kasih kepada Keuchik Gampong Lhok Bubon yang memberikan izin melakukan kegiatan sosialisasi pengenalan potensi sumberdaya kelautan dengan pendekatan bioprospeksi kelautan sehingga menambah khazanah ilmu pengetahuan bagi masyarakat pesisir.

c. Masyarakat pesisir Lhok Bubon dan mahasiswa yang antusias ikut serta dalam kegiatan pengabdian kepada masyarakat.

\section{DAFTAR PUSTAKA}

Primack I, Richard B. 1998. Biologi konservasi. Yayasan Obor Indonesia. Jakarta

Salim Z dan Munadi E. 2017. Info Komoditi Tanaman Obat. Badan Pengkajian dan Pengembangan Perdagangan. Badan Pengkajian dan Pengembangan Perdagangan. Kementerian Perdagangan Republik Indonesia Jakarta.

Gazali M, Nurjanah, Zamani NP. 2018. Eksplorasi senyawa bioaktif alga cokelat Sargassum sp. Agardh sebagai antioksidan dari Pesisir Barat Aceh. Jurnal Pengolahan Hasil Perikanan Indonesia. 21(1): 167-178. 